\title{
Antibacterial effect of some wild medicinal plants in Palestine against multidrug resistant Escherichia coli clinical isolate
}

\section{Lubna Abdallah* and Ghadeer Omar}

Department of Biology \& Biotechnology. Faculty of Science. An-Najah National University. Nablus. Palestine.*Email: alubna@najah.edu.

\begin{abstract}
Due to the emergence of antibiotic resistant pathogens, plants are being an excellent alternate to fight the further spread of multidrug resistant microorganisms. In this study, six plant species grown wildly in Palestine were used to determine their efficacy against multidrug resistant clinical isolate of Escherichia coli. The dried areal parts of Calamintha incana, Lupins pilosus, Parietaria judica, Satureja thymbra, Thymbra spicata and Verbascum fruticulosum were extracted with water, ethanol and methanol solvents. All extracts were screened for their antibacterial activity using micro-dilution method. Plant extraction with alcohol solvents provided stronger antibacterial effect compared to the aqueous ones. All alcoholic extracts have an inhibitory effect against $E$. coli except the ethanol extract of $L$. pilosus and the methanol extracts of $V$. fruticulosum and $C$. incana. Moreover, $C$. incana aqueous extract was the only aqueous extract with bacteriostatic activity. Among the studied plant species, ethanol extract of $T$. spicata was the most potent one with MBC value $12.5 \mathrm{mg} / \mathrm{mL}$. However, $P$. judica ethanol extract which exhibited the best MIC effect $(6.25 \mathrm{mg} / \mathrm{mL})$ killed $E$. coli isolate at a $25 \mathrm{mg} / \mathrm{mL}$. In conclusion, obtained results confirmed the efficacy of using some plant extracts as natural antibacterial alternatives. Therefore, it suggests the possibility of using them as drugs for the treatment of other multidrug resistant bacterial isolates.
\end{abstract}

Keywords: Antibacterial; Multidrug resistant; Escherichia coli; Plant extracts; Palestine.

\section{Introduction}

The antimicrobial resistance of bacterial pathogens has increased worldwide as a result of the extensive use of broad-spectrum antimicrobials. Therefore, the emergence of multidrug resistant (MDR) strains of various bacterial species caused serious challenges for effective medical treatment (Guardabassi et al., 2004;
Garcia-Migura et al., 2014). Due to the scarcity of effective antibacterial agents available to cure infections caused by MDR strains in general and E. coli in particular, the rate of morbidity and mortality have increased (Coates et al., 2002; Howard et al., 2003). Similar resistance were recognized in E.coli, which is a Gram-negative bacterium that has a wide range of genomic diversity. This bacterium causes many infections, 
including neonatal meningitis, septicemia, urinary tract infection, sepsis and diarrhea (Mellata, 2013). In addition to that, E. coli is a common pathogen that is linked with community-associated and nosocomial infections (Oteo et al., 2005; Drago et al., 2010).

Hence herbal alternative medicine has always been known with its rich source for the creation and development of potentially new drugs (Alam et al., 2009), recently, many scientists have paid attention to the active phytochemicals. These active compounds have been of a great interest for scientists working on infectious diseases (Essawi and Srour, 2000). The antimicrobial assay investigation of the medicinal plants may yield the discovery of new potential bioactive plant components. Therefore, the determination of antimicrobial susceptibility of multidrug resistant $E$. coli strain to different plant species extracts was carried out. Six wild plant species in Palestine which are Calamintha incana (Candargy) Govaerts., Lupins pilosus L., Parietaria judica L., Satureja thymbra L., Thymbras picata L. and Verbascum fruticulosum Post were used in this research. Those plant species were chosen in this study according to their previous known several bioactivities.

The genus Calamintha (Lamiaceae) species were used in the folk medicine as their leaves and flowers were known with their effective antiseptic and antispasmodic properties (Small, 2006). This work in with the fact that their essential oils are characterized by antimicrobial and antispazmodic activity (Kitic et al., 2002; Kürkçüoglu et al., 2007; Brankovic et al., 2009). Moreover, since (Leguminosae) the analysis of lupins constituents revealed that alkaloids are the major antimicrobial agents in all lupins species (Kinghorn and Balandrin, 1984; Wink, 1993), L. pilosus (Leguminosae) was another target plant species in this study. Several studies regarding the antimicrobial potential of crude extracts and phytochemicals from different lupins species gave evidence that they had antimicrobial activity one of which against E. coli (Obeidat, 2012; AliShtayeh et al., 2013). Furthermore, P. judaica which is known as Pellitory of the wall from the Family Urticaceae was also explored in this work. This plant species has been valued in herbal medicine (Giachetti et al., 1986), which coincide with the out finding that it had antibacterial activity against multidrug resistant Streptococcus pneumoniae isolate (Fares et al. 2013). In addition, among the studied plant species is S. thymbra (Lamiaceae), which is with essential oils of variable antibacterial effects against $E$. coli (Gören et al., 2004; Azaz et al., 2005; Markovic et al., 2011; Giweli et al., 2012). Moreover, T. spicata (Lamiaceae) was investigated for its antibacterial bioactivity. It is commonly used in the traditional medicine system in Iran, Turkey, Greece, Egypt and in Romans to treat asthma and bronchitis (Mahasneh and El-Oqlah, 1999). This could be referred to the presence of carvacrol, thymol, camphor, and 1,8cineole in the essential oils (Markovic et al., 2011), which go along with the recognized antimicrobial activity against pathogenic bacteria including $E$. coli. (Kılıç, 2006; Akin et al., 2010; Markovic et al., 2011). Over and above Verbascum fruticulosum (Scrophulariaceae) was inquired in this treatise, on the account of flavonoids, phenylethanoid and neolignan glycosides, saponins, iridoid and monoterpene glycosides presence (Tatli and Akdemir, 2004). It has been evaluated regarding other Verbascum species effects on E. coli. (Şengül et al., 2005; Sener and Dulger, 2009; Ozcan et al., 2011; Kahraman et al., 2011; Morteza-Semnani et al., 2013).

\section{Materials and methods}

\section{Antibiotic screening assay}

The antibacterial activity of the prepared plant extracts was tested 
against a clinical isolate of $E$. coli that was obtained from Rafidia hospital, Nablus, Palestine.

The antibiotic susceptibility pattern of this clinical isolate was carried out using Muller Hinton agar plates and thirteen antibiotics which are vancomycin, chloramphenicol, erythromycin, clindamycin, tetracycline, oxacillin, methicillin, ciprofloxacin, fusidic acid, imipenem, aztreonam, ceftazidime and gentamicin (NCCLS, 1999).

\section{Plant materials}

Plant species, C. incana (1410), $L$. pilosus (829), P. judica (1692), S. thymbra (1365), T. spicata (551) and $V$. fruticulosum (1695), were collected from different locations in West Bank, Palestine. The six plant species were identified by Ghadeer Omar, Department of Biology \& Biotechnology, An-Najah National University, Palestine.

Representative plant specimens were pressed till drying, treated chemically, mounted on herbarium sheets and provided with voucher numbers and then they were deposited at An-Najah National University herbarium. For the antibacterial assay, the aerial parts of plant materials were washed, air dried, ground into powder using grinder and stored at room temperature until they were used.

Ten grams of each plant powder were soaked in $100 \mathrm{ml}$ boiled distilled water for one week with interval shaking. Then the mixtures were centrifuged for $5 \mathrm{~min}$ at $5000 \mathrm{rpm}$. The supernatants were evaporated by freezedrying. The extracted powder of each plant species was dissolved in distilled water to a final concentration equal to $100 \mathrm{mg} / \mathrm{ml}$ (Omar et al., 2013).

\section{Alcoholic extraction}

Ten grams of each plant powder were soaked in $100 \mathrm{~mL}$ of $70 \%$ ethanol for one week with interval shaking. Then the mixtures were centrifuged for $5 \mathrm{~min}$ at $5000 \mathrm{rpm}$. The supernatants were evaporated by rotary evaporator. The extracted powder of each plant species was dissolved in $10 \%$ dimethyl sulfoxide (DMSO) to a final concentration equal to $100 \mathrm{mg} / \mathrm{mL}$. The same procedure was used to prepare methanol extract (Omar et al., 2013).

\section{Antibacterial activity assay}

Minimum inhibitory concentration (MIC) for all plant extracts under study was carried out by microbroth dilution method (NCCLS, 2000). The prepared extract was serially diluted two fold in Muller Hinton broth medium. Duplicates of each dilution (50.0, 25.0, $12.5,6.25,3.125,1.563,0.7810 .391$, 0.195 and $0.098 \mathrm{mg} / \mathrm{mL}$ ) were inoculated with $1 \mu \mathrm{L}$ from $5 \times 10^{7} \mathrm{CFU} / \mathrm{mL}$ adjusted bacterial cell suspension. The last two duplicate wells were not inoculated as negative controls. Then, the inoculated micro titer plates were incubated at $37{ }^{\circ} \mathrm{C}$ for $18 \mathrm{~h}$. The lowest extract concentration that inhibited the growth of tested microorganisms was considered as MIC. After that, the contents of the wells resulting from MIC was streaked using a sterile cotton swabs on Muller Hinton agar plate free of antibacterial agents and incubated at 37 ${ }^{\circ} \mathrm{C}$ for $18 \mathrm{~h}$. The lowest concentration of the extract which showed no bacterial growth was considered as minimum bactericidal concentration (MBC).

\section{Results}

The antibiotic sensitivity patterns of the E. coli clinical isolate under study showed that it is resistant to all examined antibiotics except for chloramphenicol and imipenem (Table 1). 
Table 1. Susceptibility of Escherichia coli* isolate to 13 antibiotics.

\begin{tabular}{lcc}
\hline \multicolumn{1}{c}{ Antibiotic } & & $\begin{array}{c}\text { E. coli } \\
\text { inducibility }\end{array}$ \\
\hline Methicillin (5) & MET & $\mathrm{R}$ \\
Ceftazidime (30) & CAZ & $\mathrm{R}$ \\
Oxacillin (1) & OX & $\mathrm{R}$ \\
Clindamycin & $\mathrm{DA}$ & $\mathrm{R}$ \\
Vancomycin (30) & $\mathrm{VA}$ & $\mathrm{R}$ \\
Tetracyclin (30) & $\mathrm{TE}$ & $\mathrm{R}$ \\
Gentamicin (10) & $\mathrm{GM}$ & $\mathrm{R}$ \\
Erythromycin (15) & $\mathrm{E}$ & $\mathrm{R}$ \\
Ciprofloxacin (5) & $\mathrm{CIP}$ & $\mathrm{R}$ \\
Imipenem (10) & $\mathrm{IPM}$ & $\mathrm{S}$ \\
Fusidic acid (10) & $\mathrm{FD}$ & $\mathrm{R}$ \\
Aztreonam (30) & $\mathrm{ATM}$ & $\mathrm{R}$ \\
Chloramphenicol (30) & $\mathrm{C}$ & $\mathrm{S}$ \\
\hline
\end{tabular}

${ }^{*}$ E. coli was tested on Muller Hinton agar. R: resistant; S: sensitive.

The antibacterial effect of the studied plant species on the E. coli clinical isolate was determined by the measurement of their minimum inhibitory concentration (MIC) (Table 2).

Table 2. Antibacterial activity of aqueous, ethanol and methanol extracts of the studied plant species on multidrug resistant Escherichia coli clinical isolate.

\begin{tabular}{lccc}
\hline Plant species & Extract & MIC* & MBC** \\
\hline \multirow{3}{*}{ Calimentha incana } & Water & 25 & $>50$ \\
& Ethanol & 25 & $>50$ \\
& Methanol & 0 & 0 \\
\hline \multirow{3}{*}{ Thymbra spicata } & Water & 0 & 0 \\
& Ethanol & 12.5 & 12.5 \\
& Methanol & 50 & $>50$ \\
\hline \multirow{3}{*}{ Lupinus pilosus } & Water & 0 & 0 \\
& Ethanol & 0 & 0 \\
& Methanol & 50 & $>50$ \\
Parietaria judica & Water & 0 & 0 \\
& Ethanol & 6.25 & 25 \\
& Methanol & 50 & $>50$ \\
\hline \multirow{3}{*}{ Verbascum fruticulosum } & Water & 0 & 0 \\
& Ethanol & 50 & $>50$ \\
& Methanol & 0 & 0 \\
\hline \multirow{2}{*}{ Satureja thymbra } & Water & 0 & 0 \\
& Ethanol & 50 & 50 \\
\hline
\end{tabular}

*MIC: minimum inhibitory concentration.

**MBC: minimum bactericidal concentration. 
The obtained MIC results revealed that all plant species under study obtain good antibacterial activity against the examined multidrug resistant $E$. coli isolate with observed variation among them. The recorded results showed the higher antibacterial effect of the plant alcohol extracts than aqueous ones. Nevertheless, the aqueous extracts of $C$. incana had an inhibitory effect. However, all plant methanol extracts have had inhibitory effect against $E$. coli isolate except $V$.fruticulosum and C. incana ones. Similarly, the ethanol extract of $L$. pilosus was the only one among the ethanol extracts that did not have bacteriostatic activity. Furthermore, results provided that the ethanol extract of $P$. judica exhibited the highest antibacterial activity with MIC value equal to $6.25 \mathrm{mg} / \mathrm{mL}$ (Figure 1).

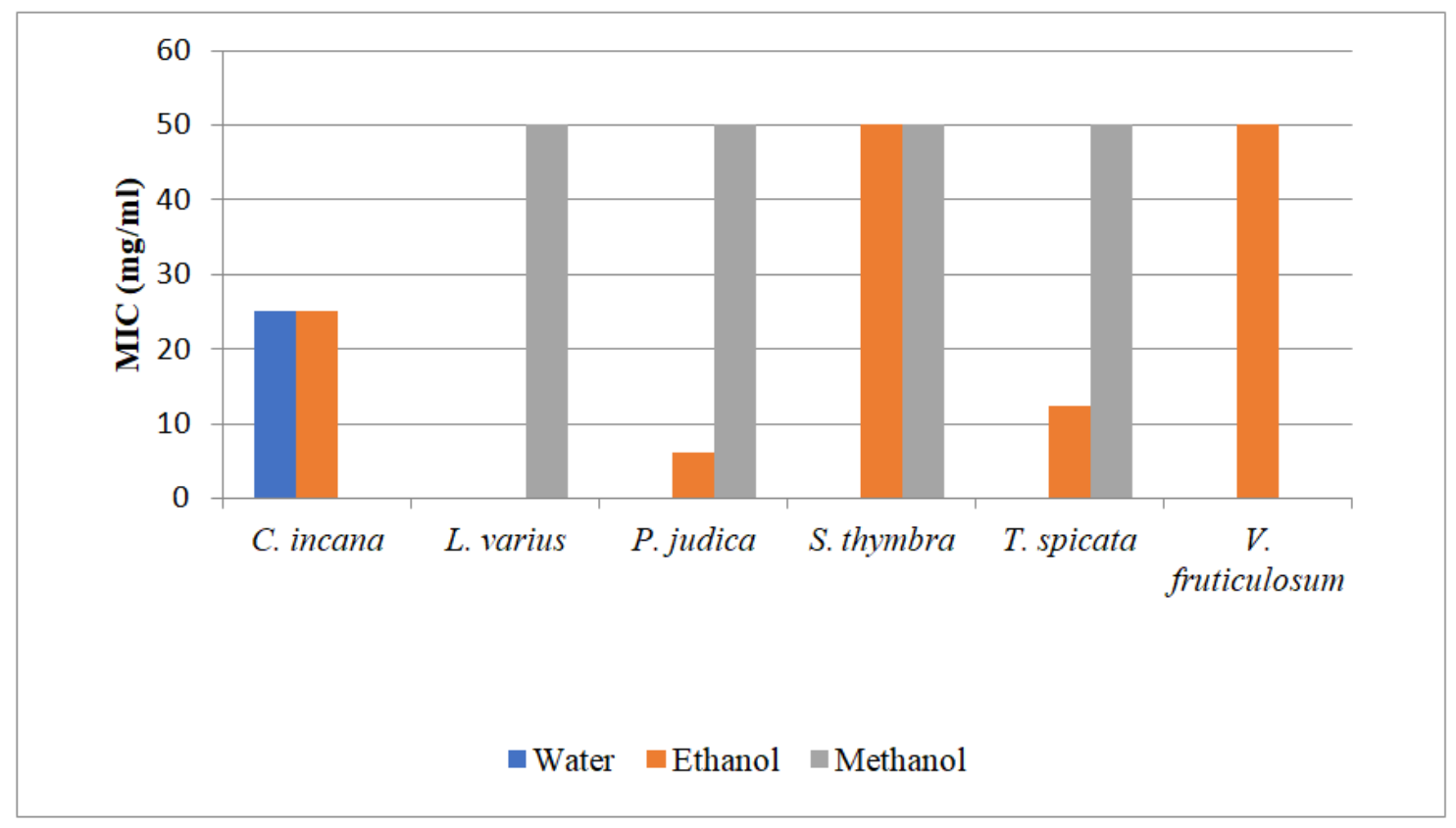

Figure 1. Antibacterial activity of Calamintha incana, Lupins pilosus, Parietaria judica, Satureja thymbra, Thymbras picata and Verbascum fruticulosum different extracts against multidrug resistant Escherichia coli isolate using micro-broth dilution method. MIC: minimum inhibitory concentration $(\mathrm{mg} / \mathrm{mL})$.

Moreover, the bactericidal effect of all plant extracts that exhibited inhibitory effect was determined by measuring the minimum bactericidal concentration (MBC) (Table 2). The obtained MBC results confirmed that the ethanol extract of $T$. spicata was the most potent extract as it had a bactericidal effect at $12.5 \mathrm{mg} / \mathrm{mL}$ concentration. But
$P$. judica ethanol extract which exhibited the most potent MIC effect killed the multidrug resistant $E$. coli isolate at a concentration equal to $25 \mathrm{mg} / \mathrm{mL}$. In addition to that, both alcoholic extracts of $S$. thymbra showed bactericidal activity against examined $E$. coli isolate at $50 \mathrm{mg} / \mathrm{mL}$ (Figure 2). 


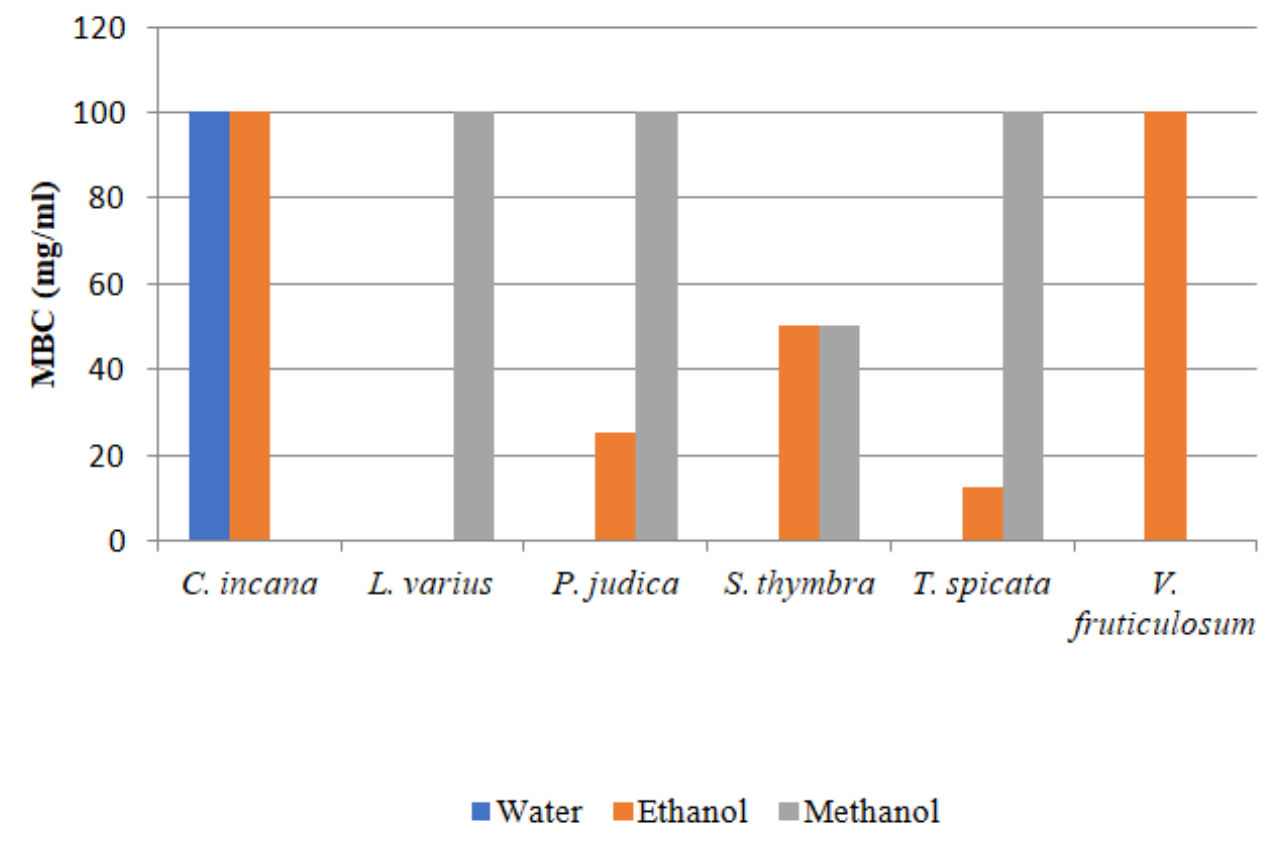

Figure 2. Antibacterial activity of Calamintha incana, Lupins pilosus, Parietaria judica, Satureja thymbra, Thymbras picata and Verbascum fruticulosum different extracts against multidrug resistant Escherichia coli isolate. (MBC) minimum bacteriocidal concentration (mg/mL).

\section{Discussion}

Escherichia coli isolates of the Enterobacteriaceae Family are considered as one of the most important bacterial pathogens that are associated with gastrointestinal tract infections and extraintestinal infections including those of the urinary, respiratory and reproductive tracts (Beutin, 1999). Due to the short expectancy of the antimicrobial agents families, it is urgent to find out new ones. Therefore, researchers are usually focusing on natural products to develop better medications against multidrug resistant microbial strains (Miyasaki et al., 2010). Plants secondary metabolites are examples for those natural products which are used in the pharmaceutical industry (Nasim and Dhir, 2010). In order to explore the possible antimicrobial effects of the plant natural ingredients, several studies emphasized on their mechanism of action against different microbes (Montanari et al., 2012). These mechanisms vary greatly depending on the components of the plant essential oils and other plant parts (Reichling et al., 2009). The antimicrobial potency of plants is believed to be due to tannins, sponins, phenolic compounds, essential oils, and flavonoids (Serrano et al., 2009).

The main aim of the current study was to determine the antibacterial susceptibility of multidrug resistant E.coli strain to different extract types from some medicinal plants that grow widely in Palestine. The studied plant species were C.incana, L.pilosus, P. judica, S. thymbra, T. spicata and $V$. fruticulosum. The efficacy of these plant extracts was quantitatively determined by measuring their MIC and MBC values.

In spite that few studies considered the antibacterial behavior of $P$. judica, the obtained results showed that it exerted a promising antibacterial 
effect against the multidrug resistant clinical isolate of E.coli under investigation. As the best bacteriostatic agent found to be the ethanol extract of P. judica with MIC value equal to 6.25 $\mathrm{mg} / \mathrm{mL}$. Other studies showed that the aqueous and ethanol extracts of $P$. judica have had moderate bioactivity against multidrug resistant Streptococcus pnemonae isolate (Fares et al., 2013). In addition to that, the best bactericidal agent in the current study was found to be the ethanol extract of $T$. spicata. In this aspect, other studies confirmed the antibacterial effect for T. spicata essential oils on different E. coli strains (Kılıç, 2006; Markovic et al., 2011). This agrees with the obtained results in the upright study. On the contrary, E. coli ATCC 25922 was unsusceptible to T. spicata essential oils and crude extracts (Akin et al., 2010; Omar et al., 2013). Such contradictions could be referred to the genotype variations among different examined E. coli strains as well as to the plant extraction methodology and type.

Most of the ethanol and methanol extracts as well as the essential oils of some Verbascum species showed no or weak antibacterial activity on other studied E. coli strains (Şengül et al., 2005; Sener and Dulger, 2009; Kahraman et al., 2011; Ozcan et al., 2011; MortezaSemnani et al., 2013). Therefore, $V$. fruticulosum different extract types were examined against the multidrug resistant E. coli, revealing an antibacterial activity of only its ethanol extract. This out finding goes along with what was recorded in previous studies.

Moreover, in spite that a studied E. coli strain showed susceptibility to L. pilosus methanol, ethanol and water extracts (Obeidat et al., 2012), the current examined isolate was susceptible only to the methanol extract of $L$. pilosus.

The running study showed that the examined alcoholic extracts from $S$. thymbra had a potent bioactivity against the examined multidrug resistant $E$. coli isolate, which go along with other studies. Not with standing, that all previous investigations were on the essential oils of different species of $S$. thymbra on E. coli strains (Azaz et al., 2005; Eftekhara et al., 2009; Askun et al., 2012; El Beyrouthy et al., 2013). Furthermore, despite that all aqueous extracts of all examined plant species showed no antibacterial activity, C. incana aqueous extract has had efficacy on the studied E. coli isolate. Similarly, its ethanol extract exhibited an antibacterial effect, while the methanol extract with no effect. Those recorded data synchronize with those cited in literatures. There with, other studies followed other extractions and other Calamintha species (Kitic et al., 2002; Kürkçüoglu et al., 2007; Btissam et al., 2018).

Thus plant extracts contain variable constituents with different bioactivity based on the type of extraction of a particular plant species. This efficacy could be related to various degree of solubility of different molecules (Silva et al., 2009). Moreover the observed variation in this study and other studies could be related to chemotype, location, collection period and vegetation cycle of the examined plant species (Gobbo-Neto and Lopes, 2007).

\section{Conclusion}

It is interesting to note that the crude extracts of these plants showed pronounced activity against the multidrug resistant E. coli strain up on which antibiotic therapy has failed. The extracts of the studied plant species could be possible source for effective medication treat infectious multidrug resistant strains of microorganisms. However, it is necessary to determine the toxicity of their active ingredients and their side effects. 


\section{Acknowledgments}

We are grateful to Biology and Biotechnology Department at An-Najah National University for allowing us to access their facilities.

\section{Conflict of interest}

Authors declare that they have no conflict of interests.

\section{References}

Akin, M.; Oguz, D.; Saraçoğlu, H. T. Antibacterial activity of essential oil from Thymbra spicata var. spicata L. and Teucrium polium (Stapf Brig.). International Journal of Pharmaceutic al and Applied Sciences, v. 1 , no. 1 , p. 55-58, 2010.

Alam, M. T.; Karim, M. M.; Khan, S. N. Antibacterial activity of different organic extracts of Achyranthes aspera and Cassia alata. Journal of Scientific Research, v. 1, no. 2, p. 393-398, 2009. https://doi.org/ 10.3329/jsr.v1i2.2298

Ali-Shtayeh, M. S.; Al-Assali, A. A.; Jamous, R. M. Antimicrobial activity of Palestinian medicinal plants against acne-inducing bacteria. African Journal of Microbiology Research, v. 7, no. 21, p. 2560-2573, 2013. https://doi.org/10.5897/AJMR12.1875

Askun, T.; Tümen, G.; Satıl, F.; Karaarslan, D. Active constituents of some Satureja L. species and their biological activities. African Journal of Microbiology Research, v. 6, no. 22, p. 4623-4633, 2012. https://doi.org/ 10.5897/AJMR11.012

Azaz, A. D.; Kürkcüoglu, M.; Satil, F.; Can Baser, K. H.; Tümen, G. In vitro antimicrobial activity and chemical composition of some Satureja essential oils. Flavour and Fragrance Journal, v. 20, no. 6, p. 587-592, 2005. https://doi.org/10.1002/ffj.1492

Beutin, L. Escherichia coli as a pathogen in dogs and cats. Veterinary Research, v. 30, no. 2/3, p. 285-298, 1999.
Brankovic, S. V.; Kitic, D. V.; Radenkovic, M. M.; Veljkovic, S. M.; Golubovic, T.D. Calcium blocking activity as a mechanism of the spasmolytic effect of the essential oil of Calamintha glandulosa Silic on the isolated rat ileum. General Physiology and Biophysics, v. 28, special issue, p. 174-178, 2009.

Btissam, R.; Fatima, E.; Kamal, E.; Hassane, G.; Mohamed, N. Composition and antibacterial activity of hydro-alcohol and aqueous extracts obtained from the Lamiaceae Family. Pharmacognosy Journal, v. 10, no. 1, p. 81-91, 2018. https://doi.org/10.5530/ pj.2018.1.16

Coates, A.; Hu, Y.; Bax, R.; Page, C. The future challenges facing the development of new antimicrobial drugs. Nature Review: Drug Discovery, v. 1, p. 895-910, 2002. https://doi.org/10.1038/nrd940

Drago, L.; Nicola, L.; Mattina, R.; Vecchi, E. D. In vitro selection of resistance in Escherichia coli and Klebsiella spp. at in vivo fluoroquinolone concentrations. BMC Microbiology, $\quad 10: 119, \quad 2010$. https://doi.org/10.1186/1471-2180-10-119

Eftekhara, F.; Raeia, F.; Yousefzadi, M.; Ebrahimic, S. N.; Hadiand, J. Antibacterial activity and essential oil composition of Satureja spicigera from Iran. Zeitschrift für Naturforschung C, v. 64, p. 20-24, 2009. https://doi.org/10.1515/znc-2009-1-204

El Beyrouthy, M.; Darwish, M.; Wakim, L. H.; Dhifi, W.; Jaoudeh, C. A.; Mnif, W.; Arnold, N.; Bouez, J. Antimicrobial activity and chemical composition of the essential oil of Satureja thymbra L. from Lebanon and comparison with its major components. In: Méndez-Vilas, A. Worldwide research efforts in the fighting against microbial pathogens: From basic research to technological developments. Boca Raton: Brown Walker, 2013. p. 53-57.

Essawi, T.; Srour, M. Screening of some Palestinian medicinal plants for antibacterial activity. Journal of Ethnopharmacology, $\begin{array}{lll}\text { v. } 70, \quad \text { no. } 3, & \text { p. } 343-349, & 2000 .\end{array}$ https://doi.org/10.1016/S0378-8741(99) 00187-7 
Fares, S.; Omar, G.; Abdallah, A.; Almasri, M.; Slaileh, A.; Zurba, Z. Antibacterial activity of selected Palestinian wild plant extracts against multidrug-resistant clinical isolate of Streptococcus pneumoniae. Journal of Pharmacy Research, v. 1, no. 10, p. 963-969, 2013.

Garcia-Migura, L.; Hendriksen, R. S.; Fraile, L.; Aarestrup, F. M. Antimicrobial resistance of zoonotic and commensal bacteria in Europe: The missing link between consumption and resistance in veterinary medicine. Veterinary Microbiology, v. 170 , no. $1 / 2$, p. 1-9, 2014. https://doi.org/10.1016/ j.vetmic.2014.01.013

Giachetti, D.; Taddei, E.; Taddei, I. Diuretic and uricosuric activity of Parietaria judaica L. Bollettino della Società Italiana di Biologia Sperimentale, v. 62, no. 2, p. 197-202, 1986.

Giweli, A.; Džamić, A. M.; Soković, M.; Ristić, M. S.; Marin, P. D. Antimicrobial and antioxidant activities of essential oils of Satureja thymbra growing wild in Libya. Molecules, v. 17, no. 5, p. 4836-4850, 2012. https://doi.org/10.3390/molecules1705483 6

Gobbo-Neto, L.; Lopes, N. P. Medicinal plants: Factors of influence on the content of secondary metabolites. Química Nova, v. 30, no. 2 , p. 374-381, 2007. https://doi.org/ 10.1590/S0100-40422007000200026

Gören, A. C.; Topçu, G.; Bilsel, G.; Bilsel, M.; Wilkinson, J. M.; Cavanagh, H. Analysis of essential oil of Satureja thymbra by hydrodistillation, thermal desorber, and headspace GC/MS techniques and its antimicrobial activity. Natural Product Research, v. 18, no. 2, p. 189-195, 2004. https://doi.org/10.1080/147864103100016 08145

Guardabassi, L.; Schwarz, S.; Lloyd, D. H. Pet animals as reservoirs of antimicrobialresistant bacteria. Journal of Antimicrobial Chemotherapy, v. 54, no. 2, p. 321-332, 2004. https://doi.org/10.1093/jac/dkh332

Howard, D. H.; Scott, R. D.; Packard, R.; Jones, D. The global impact of drug resistance. Clinical Infectious Diseases, v. 36, Suppl. 1, p. S4-S10, 2003. https://doi.org/10.1086/ 344656
Kahraman, Ç.; Ekizoğlu, M.; Kart, D.; Akdemir, Z. Ş.; Tatli, I. Antimicrobial activity of some Verbascum species growing in Turkey. FABAD Journal of Pharmaceutical Sciences, v. 36, p. 11-15, 2011.

Kılıç, T. Analysis of essential oil composition of Thymbra spicata var. spicata: Antifungal, antibacterial and antimycobacterial activities. Zeitschrift für Naturforschung C, v. 61, no. 5/6, p. 324-328, 2006. https://doi.org/ 10.1515/znc-2006-5-604

Kinghorn, A. D.; Balandrin, M. F. Quinolizidine alkaloids of the Leguminosae: Structural types, analysis, chemotaxonomy, and biological activities. In: Pelletier, W. S. (Ed.). Alkaloids: Chemical and biological prespectives. New York: Wiley, 1984, v. 2. p. 105-148.

Kitic, D.; Jovanovic, T.; Ristic, M.; Palic, R.; Stojanovic, G. Chemical composition and antimicrobial activity of the essential oil of Calaminfha nepeta (L.) Savi ssp. glandulosa (Req.) P. W. Ball from Montenegro. Journal of Essential Oil Research, v. 14, no. 2, p. 150-152, 2002. https://doi.org/10.1080/ 10412905.2002.9699802

Kürkçüoglu, M.; Iscan, G.; Ozek, T.; Baser, K. H. C.; Alan, S. Composition and antimicrobial activity of the essential oils of Calamintha betulifolia Boiss. et Bal. Journal of Essential Oil Research, v. 19, p. 285-287, 2007. https://doi.org/10.1080/10412905.2007.96 99282

Mahasneh, A. M.; El-Oqlah, A. A. Antimicrobial activity of extracts of herbal plants used in the traditional medicine of Jordan. Journal of Ethnopharmacology, v. 64, no. 3, p. 271276, 1999. https://doi.org/10.1016/S03788741(98)00132-9

Marković, T.; Chatzopoulou, P.; Šiljegović, J.; Nikolić, M.; Člija, J.; Ćirić, A.; Soković, M. Chemical analysis and antimicrobial activities of the essential oils of Satureja thymbra L. and Thymbra spicata L. and their main components. Archives of Biological Sciences, v. 63, no. 2, p. 457-464, 2011. https://doi.org/10.2298/ABS1102457M

Mellata, M. Human and avian extraintestinal pathogenic Escherichia coli: Infections, zoonotic risks, and antibiotic resistance trends. Foodborne Pathogens and Disease, 
v. 10, p. 916-932, 2013. https://doi.org/ 10.1089/fpd.2013.1533

Miyasaki, Y.; Nichols, W. S.; Morgan, M. A.; Kwan, J. A.; Van Benschoten, M. M.; Kittell, P. E.; Hardy, W. D. Screening of herbal extracts against multi-drug resistant Acinetobacter baumannii. Phytotherapy Research, v. 24, no. 8, p. 1202-1206, 2010. https://doi.org/ $10.1002 /$ ptr.3113

Montanari, R. M.; Barbosa, L. C.; Demuner, A. J.; Silva, C. J.; Andrade, N. J.; Ismail, F. M.; Barbosa, M. C. Exposure to Anacardiaceae volatile oils and their constituents induces lipid peroxidation within food-borne bacteria cells. Molecules, v. 17, no. 8, p. 9728-9740, 2012. https://doi.org/10.3390/molecules 17089728

Morteza-Semnani, K.; Saeedi, M.; Akbarzadeh, M. Chemical composition and antimicrobial activity of the essential oil of Verbascum thapsus L. Journal of Essential Oil Bearing Plants, v. 15, no. 3, p. 373-379, 2013. https://doi.org/10.1080/0972060X.2012.10 644063

Nasim, S. A.; Dhir, B. Heavy metals alter the potency of medicinal plants. In: Whitacre, D. (Ed.). Reviews of environmental contamination and toxicology. New York: Springer, 2010. p. 139-149. (Reviews of Environmental Contamination and Toxicology, Continuation of Residue Reviews, v. 203). https://doi.org/10.1007/978-14419-1352-4_5

NCCLS - National Committee for Clinical Laboratory Standards. Performance standards for antimicrobial susceptibility tests: Approved standards. Villanova, PA: NCCLS, 1999. (NCCLS Publication M2-A5).

NCCLS - National Committee for Clinical Laboratory Standards NCCLS. Methods for Dilution antimicrobial susceptibility tests for bacteria that grow aerobically: Approved standards. 5. ed. Wayne, PA: NCCLS, 2000. (NCCLS document M7-A5).

Obeidat, M.; Shatnawi, M.; Al-Alawi, M.; AlZu'bi, E.; Al-Dmoor, H.; Al-Qudah, M.; ElQudah, J.; Otri, I. Antimicrobial activity of crude extracts of some plant leaves. Research Journal of Microbiology, v. 7, no. 1, p.59-67, 2012. https://doi.org/ 10.3923/jm.2012.59.67
Omar, G.; Abdallah, L. A.; Ismail, S.; Almasri, M. Y. Screening of selected medicinal wild plant extracts antibacterial effect as natural alternatives. International Journal of Indigenous Medicinal Plants, v. 46, p. 12991304, 2013.

Oteo, J.; Lázaro, E.; Abajo, F. J.; Baquero, F.; Campos, J. Spanish members of EARSS. Antimicrobial-resistant invasive Escherichia coli, Spain. Emerging Infectious Diseases, v. 11, no. 4 , p. 546-553, 2005. https://doi.org/10.3201/eid1104.040699

Ozcan, B.; Esen, M.; Caliskan, M.; Mothana, R. A.; Cihan, A. C.; Yolcu, H. Antimicrobial and antioxidant activities of the various extracts of Verbascum pinetorum Boiss. O. Kuntze (Scrophulariaceae). European Review for Medical and Pharmacological Sciences, v. 15 , no. 8, p. 900-905, 2011.

Reichling, J.; Schnitzler, P.; Suschke, U.; Saller, R. Essential oils of aromatic plants with antibacterial, antifungal, antiviral, and cytotoxic properties: An overview. Forsch Komplementmed, v. 16, p. 79-90, 2009. https://doi.org/10.1159/000207196

Sener, A.; Dulger, B. Antimicrobial activity of the leaves of Verbascum sinuatum L. on microorganisms isolated from urinarytract infection. African Journal of Microbiology Research, v. 3, no. 11, p. 778-781, 2009.

Şengül, M.; Öğütçü, H.; Adigüzel, A.; Şahin, F.; Kara, A. A.; Karaman, İ.; Güllüce, M. Antimicrobial effects of Verbascum georgicum Bentham extract. Turkish Journal of Biology, v. 29, no. 2, p. 105-110, 2005.

Serrano, J.; Puupponen-Pimiä, R.; Dauer, A.; Aura, A. M.; Saura-Calixto, F. Tannins: Current knowledge of food sources, intake, bioavailability and biological effects. Molecular Nutrition and Food Research, v. 53, suppl. 2, p.S310-S329, 2009. https://doi.org/10.1002/mnfr.200900039

Silva, C. B.; Simionatto, E.; Hess, S. C.; Peres, M. T. L. P.; Simionatto, E. L.; Júnior, A. W.; Poppi, N. R.; Faccenda, 0.; Cândido, A. C. S.; Scalon, S. P. Q. Composição química e atividade alelopática do óleo volátil de Hydrocotyle bonariensis Lam (Araliaceae). Química Nova, v. 32, no. 9, p. 2373-2376, $2009 . \quad$ https://doi.org/10.1590/S010040422009000900026 
Small, E. Culinary herbs. Ottawa, Ontario, Canada: NRC Research Press, 2006.

Tatli, I.; Akdemir, Z. S. Chemical constituents of Verbascum L. species. FABAD Journal of Pharmaceutical Sciences, v. 29, p. 93-107, 2004.

Wink, M. Quinolizidine alkaloids. In: Waterman, P. (Ed.). Methods in Plant Biochemistry: Alkaloid and Sulphur compounds. London: Academic Press, 1993, v. 8. p. 197-239.

CC License information: This is an open-access article distributed under the terms of the Creative Commons Attribution License, which permits unrestricted use, distribution, and reproduction in any medium, provided the original work is properly cited. 